\title{
Masculinity, Scatology, Mooning and the Queer/able Art of Gilbert \& George: On the Visual Discourse of Male Ejaculation and Anal Penetration
}

\author{
CÜNEYT ÇAKIRLAR
}

\begin{abstract}
:
The aim of this essay is to investigate the intersections between masculinity, shame, art, anality, the abject and embodiment by focusing on a particular period of the British art duo Gilbert \& George's work in the 1990s. In their series The Naked Shit Pictures (1994), The Fundamental Pictures (1996) and The Rudimentary Pictures (1999), the duo's artistic self-performance opens a scatological narrative territory where the male body encounters its own abject fluids strategically magnified. Situating itself within the boundary between queer theory and Lacanian psychoanalysis with a particular focus on the phallus and the abject, this essay argues that Gilbert \& George's art-works mentioned above could be regarded as visual commentaries on and queer interventions into bodily anxieties of normative masculinities. It thus reads the artists' visual discourse of performative hypervisibility as a queer/ing one where the conventional male masculinity confronts simultaneously its ejaculatory bliss and its fear of anal penetration.
\end{abstract}

Keywords: queer, abject, Gilbert \& George, écriture, penetration, performance

When an image is too sharp it is maybe too normal, you have to make it speak more. We always feel everything has to be normal but not normal, to be a little bit different; if not, it is normal, it is boring, everybody knows what that is: invisible. So you have to make it strange, everything has to be strange, to speak a little more than normal. ${ }^{1}$

Paragraph 34.1 (2011): 86-104

DOI: $10.3366 /$ para.2011.0007

(C) Edinburgh University Press

www.eupjournals.com/para 
We don't want to make a homosexual art or a heterosexual art. We never wanted to do that. We want to make a sexual art. We think that's very important. ${ }^{2}$

Gilbert \& George

Queer aesthetics, according to William Haver, implies a pornographic art of existence. Haver argues that queer's obsession with and insistence on surface as 'being's most profound depth' works to undo the heteronormative constitution of sexual difference where the corporeal depth can operate only as an abyss to be veiled in the field of vision. ${ }^{3}$ What Haver embraces as queer is an erotics of critique where the queer critic's 'pornographic reading' and its 'absolute devotion to the flesh' remain the only way to 'make the [queerly] political happen'. ${ }^{4}$ This essay adopts a similarly eroticized approach towards embodiment in Gilbert \& George's artistic performance by taking into consideration the series The Naked Shit Pictures (1994), The Fundamental Pictures (1996) and The Rudimentary Pictures (1999).

While queer theory - as a cultural, theoretical, aesthetic and/or political practice in imagining different ways of knowing gender and sexuality - inhabits various critical and methodological tendencies, one might still argue that its critical agenda crystallizes around the exclusionary political economies and imageries of the heteronormative constitution of body and desire. In this regard, critical interventions into and interpretations of 'the figuration of masculine reason as disembodied body' (where norms of masculinity operate through its 'phantasmatic dematerialization') are fundamental matters of queer practice. ${ }^{5}$ Its implication of the Foucauldian emphasis on 'pleasure as an ethical substance' and 'the stylistics of life' triggers an analytical and ontological affinity between art, performance and queer/ness. ${ }^{6}$ Focusing on the performative and scatological use of the male body as receptacle, this article will discuss the operation of masculinity as a rematerialized and thus troubled referent in Gilbert \& George's artworks.

Determined to remain skeptical of the accounts of queer which either entirely "de-gay gayness" or over-gay queerness, I would like to discuss a particular period of the artists Gilbert \& George's ceuvre, their post-1990s, post-AIDS abject art. I shall investigate their visual engagement with the ontological affinities and interactions between the masculine, the penile, the phallic, the anal, the ejaculatory, the un/veiled and the naked. I wish to demonstrate how one might imagine a male and/or masculine écriture which, in enacting and managing its jouissance through anxiety, shame and abjection, 
articulates its sexual phantasmatic into the field of vision via the abject matter itself. While I remain critically attentive to the infinite queer possibilities operating through the territories of sex, gender and sexuality, my agenda might still appear to fix 'male' and 'masculine' as stable referents and transparent markers of identity. What particularly interests me here, however, is a performative artistic mode of exhausting and exploiting the normative intersections between 'male' and 'masculine' by using abject fluids as visual supplement. The issue here, as Calvin Thomas puts it aptly, 'becomes not writing about the body but writing itself as a bodily function'. ${ }^{8} \mathrm{My}$ discussion will concentrate on the ways in which Gilbert \& George's practice comes to examine the anxious intersectional space between the male and the masculine via the scatological flux, where the performatively enacted/embodied anxiety comes from '[neither] an identifiable position [nor] a positionable identity, but rather (...) a dispositional space of rifting between erotics and ethics, between the production of bodies and pleasures and the realm of knowledge and argument'. 9

In Gilbert \& George's early art-works, such as the series Cherry Blossom (1974), Bloody Life (1975), Mental (1976) and Red Morning (1977), the presence of the abject, the literalized or metaphorized emergence of blood, semen, spit, mud on streets - and even the artists' heavily drunk bodies as an 'intoxicated' mode of self-presentation was already a crucial element in their artistic agenda. This early period, however, has been argued hitherto only in terms of a queer/ed divinity, a performative enactment of an artistic downfall bleeding towards and yearning for a new awareness, a cruising for meaning outside the elitist bourgeois conventions of art (as documented as an artistic statement in their manifesto 'Art for All'), a queer performance of 'dandy/flâneur' sexualizing the urban as a heterotopic space of libidinal flows. ${ }^{10}$ The shift from this melancholic mood of cruising to a more 'sexed-up' imagery obsessed with the self and the abject within, which the artists also declared to be enjoying and celebrating as their invention, deserves particular attention: it leads the early works to gain, retrospectively, a much more visible, queer gender-consciousness. Rather than reiterating Bourguignon's argument that the artists' early work in the 1970s bears a politically gay sensibility in 'perform[ing] the closet', ${ }^{11}$ I prefer to read these inter-temporal affinities through the narrative of shame and masculinity in their art-works. Their enjoyment of fluidity in urban spatiality, or what they call 'humanization' or 'sexualization' of the city, triggers a retrospective significance because 
the aesthetic agenda of their later abject art reiterates and further exposes this earlier affinity with a foundational artistic jouissance in flow(s). ${ }^{12}$ Thus, what particularly interests me here is Gilbert \& George's scatological aesthetics in The Naked Shit Pictures (1994-5), The Fundamental Pictures (1996) and The Rudimentary Pictures (1999). These art-works engage with the norms of masculinity while visually accommodating the uncanny presence of the abject with the artists' bodies. They can also be considered further, even symptomatized, as a post-AIDS response to the contemporary trouble with sex, sexuality, body, death and risk.

Contemporary artistic technologies of queer performance operate not only within but also beyond gay and/or homoerotic/ized indexicality in various ways. My reading of Gilbert \& George will not impose a gay reference but examine what they consider as 'sexual' cited in the epigraph above. As the artists' performance operates through a de-genitalized queer homo-ness by means of 'deliberately refusing an overt homosexualization while at the same time gesturing towards an adjacent space - the artists' studio - within which a deferred, and thereby intensified, homosexualization takes place', ${ }^{13}$ I will prioritize their embodied performative play with the normative sexual referentiality of gender. The aim here will thus be to situate that 'sexual' in the intersection between the masculine and the abject by looking for a queer mode of writing (the) male body, an écriture of unveiling and reinscribing the male bliss.

There are two fundamental visual elements that dominate Gilbert \& George's imagery in these series: (i) microscopic images of bodily discharges (piss, spit, blood, spunk, shit, tears, sweat, as used in the titles of their works), and (ii) the artists' naked bodies that are usually represented as demonstrating various expressions of vulnerability visà-vis the enlarged, strategically aestheticized, coloured, 'flower-ed' images of the abject. The artists regard what they see in these enlarged crystals of abject fluids as "extraordinary flowers, weeds and trees'. ${ }^{14}$ Romanticizing and universalizing the extimacy and the uncanny materiality of these fluids, they also play with the abject's status as expenditure by investing in the aesthetics of its specular, as well as temporal, alterity: 'Every single day and every single hour the slides are different, so it is a non-stop activity that creates itself'. ${ }^{15}$ I would argue that the co-presence of the naked authorial body and its abject matters leads to a doubling of visual intensity in terms of attempting to display the phallus as an artistic strategy via a performative enactment of masculinity. The artists' vulnerable nakedness, appearing 


\section{Paragraph}

to embody and bend the notion of shame in their posing, can be considered as analogous to Amelia Jones's understanding of masculine dis/play.

In her analysis of male body-artists Yves Klein, Robert Morris, Vito Acconci, Chris Burden and Bob Flanagan, Amelia Jones focuses on the boundary between male masculinity and authorial self-consciousness within the realm of post-60s, post-Pollockian, performance art. Jones argues that a performative enactment of the masculine as an authorial function, in 'displaying and performing' the male body, could trigger critical potentials of 'shift[ing] to varying degrees away from the transcendental and singularly masculine conception of artistic authority put into place within modernism - a conception that relies on the veiling of the actual body of the artist such that his divinity (his phallic prowess) can be ensured'. ${ }^{16}$ It can be argued that the playful engagement with the body-as-phallus can trigger a de-fetishization in the context of the female: a simulacralized re-veiling of the feminine. This may lead to strategic narcissistic masquerades of the female body and femininity in order to block, bend and re-mediate the fetishistic male gaze: a territory of postmodern pastiche theoretically, politically and artistically over-exhausted. However, the unmarked realm of masculinity can also, through its inherent performative blind-spots, mobilize modes of artistic/authorial masquerades which critique its own hegemonic invisibility. In this respect, exploring the works of the male body-artists mentioned above, Jones refers to a radically masculine exploitation of the masculine authored by the male masculine: "They "play" the phallus, exploiting its conventional alignment with the male body to reinforce their own artistic authority and/or they "display" its anatomic corollary, the penis, to potentially deconstructive ends. (...) As he parodies it, so he wields it. ${ }^{17}$

By her rhetorical use of the word 'dis/play', Jones draws attention to the subversive potential of male exhibitionism and/or male masochism in body/performance art, which displays the body by means of a playful engagement with the penis/phallus boundary. She claims that exposing the male body as phallus in contemporary artistic practice could be regarded not only as a 'negotiation of masculinity from a position of femininity' 18 but also as a remarking of the de-gendered artistic ideal of modernism. What interests me particularly are the various forms that such a mode of performative 'dis/play' can take within and beyond self-consciously enacted bodily exhibitionism, and the extent to which such practices 
conceal queer/queerable aspects in their enactment of masculinity. Fixing masculine embodiment as that which is against performative excess in bodily spectacle might lead the critic to evaluate and ontologize any critical intervention in performance as feminine, feminized, feminizing. Jones's problematizations of Jackson Pollock as 'the ambivalent figure' and 'the dispersed origin' of body art, Vito Acconci as the artist of 'incoherent masculinity' and Keith Boadwee as the queer pasticher appropriating Pollock's ejaculatory virility within his anal(ized) intervention come to prioritize a mode of gender ambiguity achieved, always partially, through opening the male body to penetration. ${ }^{19}$ Reading the male body as image first presupposes a primary (innate) masculinity in conflict with the exposed and thereby feminized body and then opens a crossidentificatory subversive possibility to be undone through hyperbolic spectacle(s). The critical examination of such possibility, however, always encounters and realizes, paranoidly, the Symbolic law: such a discursive impasse in critique is considered by Sedgwick as 'kinda subversive, kinda hegemonic'. ${ }^{20}$

I would argue that a possibly critical artistic mode of exposing, exploiting or desublimating the masculine, which leads to an imagery of re-embodying the ideologically disembodied, does not necessarily guarantee what Jones conceptualizes as a cross-identificatory 'position of femininity'. Such an argument might ignore the boundaries of intersections between gender and sexuality; and, reduce queer and homoerotic investments in vision merely to a conceptually failed gender cross-identification. Hence, extrapolating, unconditionally, the masochistic, self-shattering, pathos of the male performance artist (Acconci, Burden, Flanagan) to a feminine positionality seems to me problematic. Alex Bacon's reading of Gilbert \& George appears to resonate with Jones's Lacanian grounding: '[the artists'] masculinities operate excessively, which is to say (ontologically) like femininities'. ${ }^{21}$

In this regard, I want to supplement such a discourse of masculinity operating through the heterosexually Oedipalized scenario of castration anxiety and the virile urge to transgress from within. I thus prefer to read Gilbert \& George's scatological aesthetics as a practice that performs, embodies and exposes what Calvin Thomas regards as the 'scatontological dysgraphia', the anxiety of writing - where writing functions as abjection - in the hegemonic heteronormative masculine. Situating the 'oscillating tension between (...) coherence and shattering, hyperbole and humiliation, activity and appearance, identity and difference, (...) phallocentric value and 


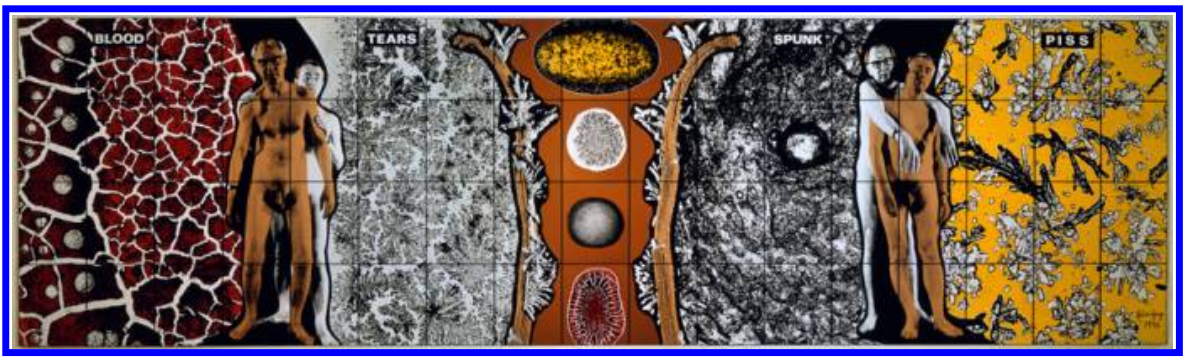

Figure 1. Gilbert and George, Blood Tears Spunk Piss, 1996. Courtesy of the Artists, Lehmann Maupin Gallery, New York and Sonnabend Gallery, New York.

abject waste ${ }^{22}$ as constitutive of such anxiety, Thomas considers 'the project of masculine self-representation' as an uneasy mode of production in self-writing due to 'the materiality of writing as visibilized speech'. ${ }^{23}$ In visualizing this phobic discourse of corporeality, enacting the anxious failure of escaping 'the inescapable alterity of the visual, ${ }^{24}$ Gilbert \& George write and pastiche the masculine anxiety of abjection.

Gilbert \& George's pastiche of gender, their performance of a self-embarrassing, self-shaming masculinity, operates in similar multifaceted layers of ambiguity and aporia, parody and seriousness. The funny is confused with the serious. Through scatological exposure, they supplement and mix the dysgraphic pathos of heteronormative masculinity with the parodic bathos of their mundane, blank, philistine self-presence in such a way that 'the affects of the one bleed into that of the other'. ${ }^{25}$

In his metaphorization of (normative) masculine writing as an anally anxious entry into language, Thomas offers the possibility of 'a conscientiously failed writing as a model of conscientiously failed masculinity': ass-fuck-as-écriture. ${ }^{26}$ Departing from Thomas's play with gender performativity and shame, Murat Aydemir prioritizes the significance of the penile and of male ejaculation in his Images of Bliss which critically investigates cross-fertilizing territories of masculinity and meaning. ${ }^{27}$ In engaging with these theoretical positions and in simultaneously reading Gilbert \& George's queer aesthetics of male bliss, I seek the constitutive visual latencies which write male ejaculation and anal penetration as mutually inclusive performatives of masculinity.

I take the visual dominance of the abject in these series, particularly the visual coexistence of shit, the male body and other liquid bodily discharges, as a further de-sublimation of masculinity in which the 


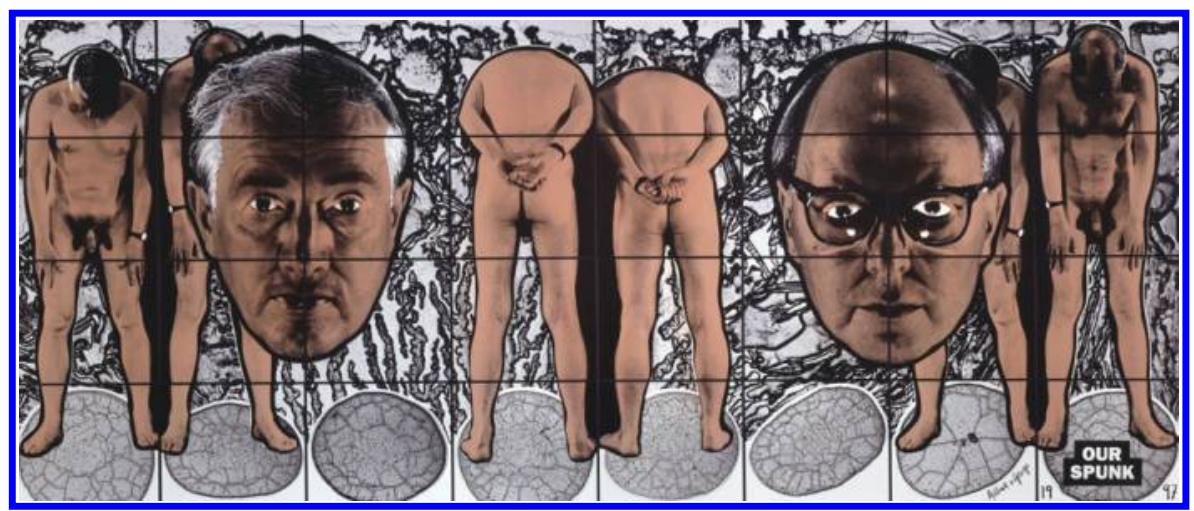

Figure 2. Gilbert and George, Our Spunk, 1996. Courtesy of the Artists and Gallerie Thaddaeus Ropac, Paris/Salzburg Photo: Charles Duprat.

artists' 'opening-up', or what Wolf Jahn calls their 'newly born awareness', is performed by means of binding the anal sublime in/of writing to a 'male' discourse of aesthetic ejaculation.

Besides the exposure of the naked male body subjugated to the gaze, the revealing of the abject as the embodiment of an artistic jouissance contains a threat to the unitary rigidity of the conventional masculine ego. The male's visual encounter with his bodily abject triggers an anxiety mainly because the abject comes to function as unveiled phallus. If one recalls that 'the phallus can only play its role as veiled [voile', would my argument, then, come only out of a naive queer desire?28 According to Aydemir, Lacan's conceptualization of the phallus already incorporates the male ejaculate as the constitutive metaphor for the phallicity of signification: '[the phallus is] the image of the vital flow as it is transmitted in generation [l'image $d u$ flux vital en tant qu'il passe dans la génération]'. ${ }^{29}$ The veiledness of the ejaculate as the vital flow (flux vital) reiterates the discursive imagery of heterosexual coitus which is presumed to impregnate meaning by 'striking [frapper]', or fucking, the so-called passive, feminine signifiable. Meaning, in Aydemir's queer Lacanianism, is the effect of this 'graphic concatenation' where the ejaculateas-phallus, in leaving only its trace or stain within the meaning, founds it. ${ }^{30}$

According to Thomas's argument, the particularly masculine anxiety of production (pro-ducere), resonating with the anxiety of the image of the abject-ejaculate, 'is not so much one of influence, (...) as one of exfluence, of excorporation, a general anxiety about flux and fluidity, 


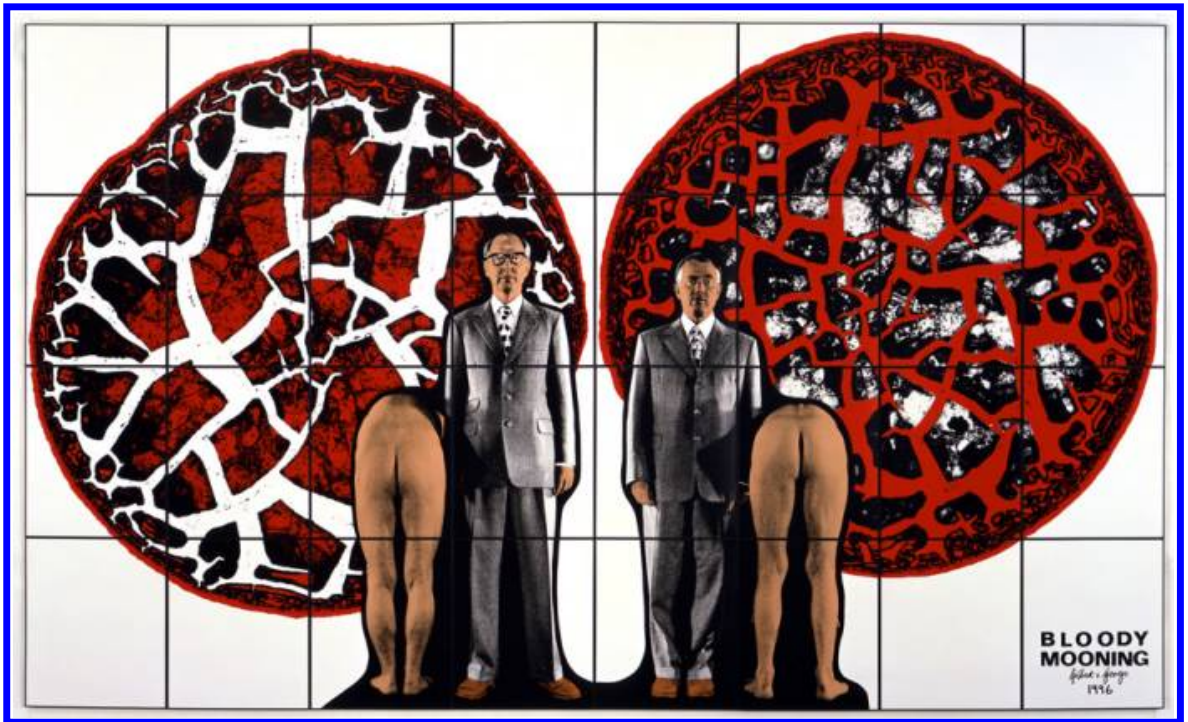

Figure 3. Gilbert and George, Bloody Mooning, 1996. Courtesy of the Artists, Lehmann Maupin Gallery, New York and Sonnabend Gallery, New York.

an unease not only about what comes out of the body but also about the ways bodies themselves originally come out'. ${ }^{31}$ Thomas claims that 'the end of all masculine excorporation becomes destruction (...) a search for a killable other', which can possibly be subverted by writing the male body in the form what I would call an écriture of a queer masculinity. ${ }^{32}$ In this sense, what I regard as an ejaculatory aesthetics signifies masculine productivity as excorporation enjoyed out of re-incorporation, whose rhetoric of penetration reveals enjoyment. The ejaculation, here, functions both literally and metaphorically. It inevitably depends on an artistic and performative enactment of the male body abjecting its discharges blissfully, where (i) the ejaculate itself as liquid appears to threaten the phallic glory of the 'solid' penis, and (ii) the transitory spatiality of the domain of abject - formulated by Kristeva as 'neither object nor subject' - between the self and the other, the subject and the object, resists the mis-recognized phallic unity - the one-ness - of ' $\mathrm{I}$ '. 33

In this respect, Irigaray's emphasis on the male negation of the semen qua liquid deserves particular attention:

We might ask (ourselves) why sperm is never treated as an objet a. Isn't the subjection of sperm to the imperatives of reproduction alone symptomatic of a preeminence historically allocated to the solid (product)? And if, in the dynamics 
of desire, the problem of castration intervenes - fantasy/reality of an amputation, of a 'crumbling' of the solid that the penis represents - a reckoning with spermfluid as an obstacle to the generalization of an economy restricted to solids remains in suspension. ${ }^{34}$

Departing from Irigaray's discussion, Murat Aydemir reevaluates Lacan's discussion of the phallus and stresses that the relationship between the male body, masculinity, shame, meaning and abject is too crucial to be ignored. Rather than reducing it to the territory of a pre-Oedipal maternal abyss of devouring femininity, Aydemir's study is an attempt to take the abject as the founding repudiation in the normative formation of the masculine ego and as that which constitutes a paradoxically castrating excess - of shame - in male bliss. If the phallus 'can only play its role as veiled [voilé], that is to say, as in itself the sign of the latency [latence] with which everything signifiable [tout signifiable] is struck [frappé], when it is raised (aufgehoben) to the function of the signifier', ${ }^{35}$ then the penile ejaculate, the semen qua liquid, or 'the phallus as the image of the vital flow' in Lacan's vocabulary, acts as the abject to be simultaneously expelled and veiled for the sake of the masculine 'I'. In this regard, recalling also Gilbert \& George's statement that 'they produce their work with their thoughts and with their souls and with their cocks', ${ }^{36}$ I would argue that the artists' abject art develops around the drive to celebrate the body as an embodiment of vital flows: their opening-up is a gesture to what Thomas calls the masculine 'anxiety of flux'. Regarding their art as an effect of their male desire and bliss ('with our cocks'), the artists' agenda of desublimating masculinity and male shame marks any representation of the abject as the (metaphor of) ejaculate, i.e. a discharge of joy. What their scatology unveils refers to what the ejaculate qua liquid appears to dis/play: the phallus. These series of images can be discussed by considering three main issues in terms of their narrative strategies of dis/play: (i) play with gaze and transfer of shame, (ii) superimposition of the naked body on the abject, and (iii) superimposition of abject on abject.

In the series The Naked Shit Pictures (1994), Gilbert \& George's imagery is dominated by their naked bodies and the pieces of shit represented as almost as large as their bodies. Naked Eye, though being in the same series but lacking shit, also presents the artists' narrative agenda of de-sublimating the universal of normative masculinity. Whereas the naked bodies of the artists that appear to embody male shame as they cover their faces with their hands come to 


\section{Paragraph}

imply both a vulnerability in nakedness and in homosexual mutuality, their monumentalized faces in the background catch the gaze of the spectator by enacting the hegemonic power in looking. The phallic presence of shit in the other pictures is used to supplement and increase their 'naked-ness' which they regard as a form of bodily vulnerability. The shit in their imagery helps them to articulate their performance of male shame to homo-specific ends. The shit in these images appears to unbury the rectum, that is, as Bersani puts it aptly, "the grave in which the masculine ideal of proud subjectivity is buried' ${ }^{37}$ In this regard, the artists formulate their opening-up as follows:

You don't need to have your eyes open to feel naked in front of another person. The other person is looking. You can concentrate on the inner feelings if you close your eyes. In some way humanity is based on hiding everything. (...) We don't believe that there is anything wrong in doing pieces to do with shit because shit is a part of us or to do with nakedness - especially of men. It's strange: a naked body is wonderful; two naked ladies, very interesting; but two men naked... One man naked is a male study; more than one, more naked than one. For us, being naked in front of the public, we are trying to make ourselves vulnerable in front of the viewer. That is very important because art is based on making ourselves more vulnerable and opening up what is inside us. We never look at what is outside the world; we always look inside the world, and this kind of picture in some way is showing the world that we are actually inside..$^{38}$

Naked Suits, Eight Shits, Naked Shit, Human Shit, Shitty World, Tops \& Bottoms, Shitty Naked Human World are several examples in this regard. ${ }^{39}$ In some of these pictures, what the artists regard as their 'responsibility suits' are still present but they operate as a transitional embodiment of queer parody, as that which fails to veil the conventional masculine anxiety of anal joy. Having already internalized an allusion to anti-bourgeois populist dandyism in their early artistic practice of the 1970s, their choice of mainstream clothing as 'a virtual uniform' in order to 'eliminate issues of choice and vanity' has been antithetical to the dandy's drive to 'set himself apart from the depersonalized subjects of the modern metropolis'. ${ }^{40}$ Stressing 'the transitory nature of capitalism and its encouragement of a dandified cult of self', Jones argues that the contemporary use of bourgeois or middle-class clothing in artistic self-performance gains a presumably simulacral excess and signifies a 'defiance' or postmodern irony: 'the artists' deployments of middle-class stability read as parodies of the 
modernist conception of a stable, unified (and implicitly masculine) western subject and by extension, of the male artist/genius' ${ }^{41}$

I would suggest that Gilbert \& George's 'responsibility suits' serve a similar performative agenda throughout their ouvre. Starting with The Naked Shit Pictures, however, the artists further manipulate this narcissistic mode of excess by using their suits for the self-conscious process of getting naked in front of the viewer. It is the artists' wilful choice to open up, to expose their vulnerability, as an artistic gesture the performative dynamics of which reiterates what they previously defined as being a human 'living sculpture'. ${ }^{42}$ What makes the coexistence of the naked male body (bums, rectal holes and penises) which are frequently juxtaposed to their 'business suits' and their photographically magnified turds a radical double exposure is the shame-gaze which they performatively throw back to the spectator. I thus read the artists' simultaneous inhabitation of male nakedness and the hyperbolically phallicized turd as not merely a homoaesthetic mode of art but a queer 'aesthetics of shame [where] shame ricochets within the self and converts into joy'. ${ }^{43}$

The bodily vulnerability enacted by their leaning on each other, bending over and exposing their buttocks and bum holes gains an increasingly sexual and political meaning in their scatological aesthetics. In the subsequent The Fundamental Pictures (1996), other bodily fluids enter the scene. The microscopic images of dried crystallized liquids - cracks in blood, flower-like patterns in piss, sweat and semen, bubbles in spit-serves an avant-gardist reappropriation of abject as readymade. The artists' bodily presence appears in various forms: cropped, visually magnified, heads being embedded in an abject landscape and gazing back to the spectator, bent-over bodies exposing the buttocks and presenting a mode of anal jouissance, frontal exposures with poses of vulnerability and interdependence, flaccid penises, and so on. I would argue that this co-presence of abject-as-phallus and the naked male body, the concurrent practice of revealing the abject-in-blossom and the male body opened-up in its submissive naked-ness as its producer/container refers to a performance of de-abjection: the artists regard this act as 'de-shocking', signifying an artistic performance of normalization through transgression, allowing the queer 'to conform [or to get sculpted] to a certain normality'. ${ }^{44}$ Hence I insist on using the metaphor of ejaculatory aesthetics: the phallus is unveiled as abjectin-blossom, the ejaculate qua intense flow of joy and vitality (not only in semen, but also in sweat, piss, spit, blood) is cultivated 
as art rather than being negated, excorporated, expelled from the masculine 'I'.

Whereas there are pictures presenting the artists with a single microscopic image of bodily fluid in the series The Fundamental Pictures (1996) and The Rudimentary Pictures (1999), the naked bodies or body parts disappear in some images and the imagery appears to be overwhelmed with visual crystals of different fluids layered onto, mixed into or positioned next to each other. The titles also demonstrate this urge to multiply the abject excess: Blood and Spit, Piss on Piss, Spit on Piss, Blood on Shit, Spunk on Blood. In some images, however, this abject heterogeneity is interrupted again by the artists' naked bodies (Spunk on Us, Blood and Piss, Piss Mooning, Bloody Mooning, Spit Naked) and/or fragments of city maps (Crying City, Blood City, Piss City, City Sweat, Love Spunk (1998)). While the artists' presence implies an enactment of a flaneur wandering in another universe, a biological microcosm, the maps allude retrospectively to the artists' vision of the city as a space of flows (e.g. their 1977 series Dirty Words) and their interest in concatenating these micro and macro universes, from a similar perspective of libidinal flows.

This further excess of disturbance, which the artists seek to 'deshock', comes from the potential of the abject matter to remind the viewer of the orifice from which it is coming. If the spectator knows that the artists use their own discharges for aesthetic magnification, the intermingling of body fluids also refers to intermingling of male body parts, thereby adding a queer excess to this visual multiplication. ${ }^{45}$ The visual co-existence of any combination of the anal (shit), the penile (piss, spunk) and the oral (spit) challenges further the masculine rigidity of 'I', which provokes what Thomas calls 'male anxiety' and catalyses the queer affinities of the imagery. The optical anxiety triggered by the intermingling of abject fluids can also be observed in Andres Serrano's series of three photographs Semen and Blood (1990). Aydemir's reading of Serrano, though gesturing at the potential of the artist's pictures in 'condens[ing] health and sickness, livingness and mortification, thus tuning onto the AIDS scare of the time and the social panic that accompanied it', strategically genders these fluids in order to gesture critically at the Aristotelian imagery of the male and the female. ${ }^{46}$ The irony between the failure of blood and semen to 'amalgamate and mingle' and 'the tangible viscosity keep[ing] them firmly together, yet apart' enables Aydemir to claim that the ambivalence in Serrano's images troubles Western culture's 'long-standing history of turning the difference between sperm and menstrual blood into an opposition, 
and of deriving a hierarchy between the sexes from it' ${ }^{47}$ Gilbert \& George's The Fundamental Pictures, The New Testamental Pictures (1998) and The Rudimentary Pictures (1999), however, deheterosexualize and considerably degenitalize both the artistic jouissance and the ontological ground of the visual critique that they perform. While the semenshit or the blood-shit couple voids the possibility of reenacting an Aristotelian allusion in their blood-semen couple, the queer presence of the artists' naked bodies bent over to the viewer (Spunk Mooning, Bloody Mooning, Piss Mooning) strategically gender and sexualize their critical target. In bending over, Gilbert \& George embody and perturb male dysgraphia by shifting it to a mode of joy. Recalling also the artists' visual infatuation with tears and sweat in these series, I see here not a traumatic but a celebratory excess in bodily depth and fuckability which is deliteralized and degenitalized through a naive discourse of hypervital corporeality. Difference becomes not evacuated but decentralized, and functions as 'a non-threatening supplement to sameness'. ${ }^{48}$

The anxiety, as well as the erotics, that Mapplethorpe provokes in his hyberbolic fetishism with the male body, penises and flowers also resonates with Gilbert \& George's discourse of abject-in-blossom in the (Genetian) sense that both exploit the normative ontological foundations of the masculine from within its primal anxiety: both radically sexualize and reveal bodily penetrability as a central mode of male and masculine bliss. Queer, in this particularly erotic visual territory, gains a meaning of a deliberate failure of straight masculinity, writing the ecstasy to fail, via an erotics of what Thomas calls a 'scatontological dysgraphia', or, 'a conscientiously failed writing as a model of conscientiously failed masculinity'. ${ }^{49}$ Although I would argue that the artists' profoundly anal/ized aesthetics demonstrates a playful but gender-specific mode of écriture functioning as a queerly 'anti-generative writing, ${ }^{50}$ their scatological art is beyond a genitally specific, identifiable, sexuality. Hence Tim Dean's defence of 'a more expansive sense of gayness in the spirit of - though differently from queerness as an especially capacious and looser understanding between sexuality and selfhood' matters a great deal here. ${ }^{51}$ If a possibly queer art is one that eroticizes, stubbornly, the body as a text of an obscene depth via an impersonal aesthetics of 'progressive degenitalization', ${ }^{2}$ Gilbert \& George's 'art of mooning' appears to perform an ethical gesture to 'the sexual' through a visual discourse of failure, shame and abject. 
100 Paragraph

\section{NOTES}

1 See 'Interview with Gilbert \& George, Saint-Etienne 2004' in the exhibition catalogue Gilbert \& George, E1, edited by Isabelle Baudino and Marie Gautheron (Lyon: ENS Editions Musée d'Art Moderne de Saint-Etienne Métropole, 2005), 56.

2 See Shere Hite's 1996 interview with the artists in Gilbert \& George, The Words of Gilbert \& George: With Portraits of the Artists from 1967 to 1997 (London: Thames \& Hudson, 1997), 288.

3 In his discussion of the ontological affinities between art and queer, Haver states: 'Art's work is an existential comportment that in its very happening acknowledges that what is at issue is not a surface that presumptively conceals the depth of being's being, but the surface that is being's most profound depth' (William Haver, 'Really Bad Infinities: Queer's Honour and the Pornographic Life', Parallax 5:4, 1999, 9-21 (13)).

4 William Haver, 'Really Bad Infinities', 20.

5 Judith Butler, Bodies That Matter: On the Discursive Limits of 'Sex' (London: Routledge, 1993), 48-9.

6 Michel Foucault, The Care of the Self: The History of Sexuality, Volume 3, translated by Robert Hurley (Harmondsworth: Penguin, 1990), 67-8. See also Michel Foucault, 'On the Genealogy of Ethics: An Overview of Work in Progress', The Essential Works of Michel Foucault, Volume 1, Ethics: Subjectivity and Truth, edited by Paul Rabinow, translated by Robert Hurley and others (London: Allen Lane, 1997), 253-80.

7 Leo Bersani, Homos (London: Harvard University Press, 1995), 42-5.

8 Calvin Thomas, Male Matters: Masculinity, Anxiety and the Male Body on the Line (Urbana: University of Illinois Press, 1996), 3.

9 Thomas, Male Matters, 7.

10 The concept 'Art for All' operates as a form of artistic statement, a signature. Throughout their artistic practice, the artists always liked to verbalize their understanding of art in the form of letters to the viewers: "We want our Art to speak across the barriers of knowledge directly to People about their Life and not about their knowledge of Art. The $20^{\text {th }}$ century has been cursed with an art that cannot be understood. The decadent artists stand for themselves and their chosen few, laughing at and dismissing the normal outsider. We say that puzzling, obscure and form-obsessed art is decadent and a cruel denial of the Life of People'. See the artists' 'What Our Art Means' (1985) in Gilbert \& George, The Words of Gilbert \& George, 149-50. For an in-depth reading of the artists' cuvre in terms of religious iconography, see Wolf Jahn, The Art of Gilbert \& George, or, an Aesthetics of Artistic Existence (London: Thames and Hudson, 1989). For a critical evaluation of contemporary male avant-gardism in visual arts in terms of the 'dandy/flâneur' figure, see Jones's discussion of 
masculinity and dressing in Amelia Jones, "Clothes Make the Man": The Male Artist as a Performative Function', Oxford Art Journal 18:2, 1995, 18-32.

11 Katherine Bourguignon, 'Performing the Closet: Grids and Suits in the Early Art of Gilbert and George', Genders 31, 2000, http://www.genders.org/ g31/g31_bourguignon.html, consulted 12 December 2010, 3.15 p.m.

12 Gilbert \& George state: "We believe very much urban is life. If you go to the country you don't feel living anymore. In this urban society, all the human beings are spitting on the floor, are leaving down chewing-gums on the floor. They are writing graffiti of anger on the walls. That's exactly the material that we like. (...) We wanted to find out the whole city is all sexual. What we try to do is to humanize the city, sexualize it, give its economic importance (...) to show the city like we feel it, not like it looks like' ('The Interview' in Gilbert \& George, E1, 30).

13 David Dibosa, 'Queer Appearances: Gilbert \& George's Visual Strategies', Sexualities 12:2, 2009, 251-62. For a neo-Leavisite critique of the aesthetic philistinism in the 1990s' young British artists, and thus Gilbert \& George as the key inspirational figure, see Julian Stallabrass, High Art Lite: British Art in the 1990s (London: Verso, [1999] 2006).

14 See Gilbert \& George, The Words of Gilbert \& George, 298-9.

15 See the 1997 interview 'The Fundamental Gilbert and George' conducted by Gerald Fox and Sarah Wason for the London South Bank Show, The Fundamental Gilbert \& George, in Gilbert \& George, The Words of Gilbert \& George, 298-302.

16 Amelia Jones, 'Dis/playing the Phallus: Male Artists Perform Their Masculinities', Art History 17:4, 1994, 546-84 (547).

17 Jones, 'Dis/playing the Phallus', 547, 563.

18 Jones, "Clothes Make the Man": The Male Artist as a Performative Function', 19.

19 Amelia Jones, Body Art/Performing the Subject (Minneapolis: University of Minnesota Press, 1998), 61-150.

20 Eve Kosofsky Sedgwick, 'Queer Performativity: Henry James's The Art of the Novel', GLQ 1:1, 1993, 15.

21 Alex Bacon, 'Punks, Skinheads and Dandies: Matrices of Desire in Gilbert \& George', in The Art of Queering in Art, edited by Henry Rogers (UCE Birmingham: Article Press, 2007), 77.

22 Thomas, Male Matters, 26.

23 Thomas, Male Matters, 16.

24 Thomas, Male Matters, 16.

25 In his reading of the drag performance of Kiki and Herb, Gavin Butt gestures to an aesthetics of ambiguity in queer theatricality where 'the performance prevents us from dwelling in one emotional frame of reference for very long, either of melodramatic pathos or comedic bathos'. Butt situates 'queer 


\section{Paragraph}

seriousness' in the performative intervention to blur 'conventional lines between opposing social and cultural categories, (...) between supposedly discrete and distinctive affective states of the heartfelt and the playful, sincerity and theatricality' (Gavin Butt, 'How I Died for Kiki and Herb', in The Art of Queering in Art, 93). See also Gavin Butt, 'Joe Brainard's Queer Seriousness', in Neo-Avant-Garde, edited by David Hopkins (Amsterdam and New York: Rodopi, 2006), 277-97. I would say that the polypathic presence in Gilbert \& George's self-representation, the pastiching gender-surface of their bodily spectacle, would be an interesting case study to be analysed in much deeper ways with Butt's concept of 'queer seriousness'.

26 Calvin Thomas, 'Must Desire Be Taken Literally?', Parallax 8:4, 2002, 46-56 (49). For Thomas's detailed conceptualization of 'scatontology' as dysgraphia operating through the centrality of abjection to male subjectivity, see Thomas, Male Matters.

27 Murat Aydemir, Images of Bliss: Ejaculation, Masculinity, Meaning (Minneapolis: University of Minnesota Press, 2007).

28 Lacan's 'Signification of Phallus' in Jacques Lacan, Écrits: A Selection, translated by Alan Sheridan (London and New York: Routledge, [1977] 2001), 220.

29 Lacan, Écrits, 220. The emphasis on the segments from the original text in French is cited from Aydemir, Images of Bliss, 42.

30 For a detailed reading of Lacan's use of 'frappé', see Aydemir, Images of Bliss, 43. I shall return to this in the later paragraphs.

31 Thomas, Male Matters, 13-14.

32 Thomas, Male Matters, 18.

33 The subject, according to Kristeva, gains its linguistic status by means of negating bodily liminality. Thus, the analysis of the abject here departs from the body itself and is then extrapolated to the territory of language, image and identity. Hence the vital attraction between the abject and the queer, in which they both appear to found, while getting repudiated/abjected by, the masculine core, the gender-identity, of the 'I': 'I abject myself within the same motion through which "I" claim to establish myself' (Julia Kristeva, Powers of Horror: An Essay on Abjection, translated by Leon S. Roudiez (New York: Columbia University Press, 1989), 3.

34 See the essay 'The "Mechanics" of Fluids' in Luce Irigaray, This Sex Which Is Not One, translated by Catherine Porter and Carolyn Burke (Ithaca: Cornell University Press, [1977] 1985), 113.

35 Lacan, Ecrits, 220. The emphasis on the segments from the original text in French is cited from Aydemir, Images of Bliss, 42.

36 Gilbert \& George, The Words of Gilbert \& George, 134.

37 Leo Bersani, 'Is the Rectum a Grave?', AIDS: Cultural Analysis, Cultural Activism, edited by Douglas Crimp (Cambridge, MA: MIT Press, 1988), 222. 
38 See the artists' remarks in Robert Rosenblum, Introducing Gilbert \& George (London: Thames \& Hudson, 2004), 128 and 132-7 (my emphasis).

39 For the images, see the exhibition catalogue Gilbert \& George, The Naked Shit Pictures, South London Gallery 5th Sept-15th Oct (Stuttgart: Oktagon, 1995).

40 Brenda Richardson, 'Gilbert \& George', Gilbert \& George (Baltimore: Baltimore Museum of Art, 1984), 8 and Jones, 'Clothes Make the Man', 32 (the commentary on Gilbert \& George in her footnote 55).

41 Jones, 'Clothes Make the Man', 27.

42 Presenting/exhibiting themselves as 'sculptures' to the viewer in the 1969 show Singing Sculptures where they sing together in loops by moving robotically on a table, they enact, in their most literalized narrative mode, their idea of being and/or becoming human sculptures as their artistic and ethical ideal, i.e. to form/sculpt life and to get formed/sculpted by life. Their performative use of business suits appears in their 1969 performance and remains as a signature throughout their cuvre.

43 With particular reference to Tracey Emin's artistic practice, Munt discusses the ways in which shame bears 'a potential for strategic disengagement and reinvention' (Sally R. Munt, Queer Attachments: The Cultural Politics of Shame (Aldershot: Ashgate, 2007), 216-9).

44 Robin Dutt, Gilbert \& George: Obsessions and Compulsions (London: Philip Wilson, 2004), 27.

45 The gender-specifity in what I read as the phantasmatic allusion to 'intermingling male body-parts' might sound problematic. However, though still resisting a reductionist reading of this in terms of a politically homosexualized visual referentiality of a gay-ly sensible signature, I prefer to put an emphasis on the artists' gesture at the intersections between shame and masculinity via the use of their own bodily discharges. They also appear to consider this as constitutive of their performative agenda. See the interview 'The Fundamental Gilbert \& George' in The Words of Gilbert \& George, 302.

46 Aydemir, Images of Bliss, 6.

47 Aydemir, Images of Bliss, 6-9.

48 Bersani, Homos, 7.

49 Thomas, 'Must Desire Be Taken Literally?', 49. Thomas's discussion departs here from Bersani's notion of 'rectum-as-grave' and Edelman's 'homographesis'. Lee Edelman, 'Homographesis', Yale Journal of Criticism 3:1, 1989, 189-207.

50 Thomas situates 'the anti-generative in writing' against 'expressivity [or] any "creativity" traditionally linked to paternity, maternity, or any other imperative of the successful heterosexual reproduction of "life", but rather on writing's intimately sexual connection, its degeneratively metonymic connection, to murderous or suicidal ecstasy, to failure, to "death" - its 


\section{Paragraph}

connection, in other words, to the rectum' (Thomas, 'Must Desire Be Taken Literally?', 49).

51 Tim Dean, Beyond Sexuality (Chicago and London: University of Chicago Press, 2000), 278.

52 Dean, Beyond Sexuality, 276. For Dean's in-depth reading of Leo Bersani's collaboration with Ulysse Dutoit on the concepts of 'expansive narcissism', 'impersonal relationality' and 'inaccurate self-replication', see Tim Dean, 'What's the Point of Psychoanalytic Criticism?', The Oxford Literary Review 20:1/2, 1999, 143-62. 